\title{
LIN9 wt Allele
}

National Cancer Institute

\section{Source}

National Cancer Institute. LIN9 wt Allele. NCI Thesaurus. Code C158450.

Human LIN9 wild-type allele is located in the vicinity of $1 \mathrm{q} 42.12$ and is approximately 79

$\mathrm{kb}$ in length. This allele, which encodes protein lin-9 homolog, is involved in tumor suppression and cell cycle regulation. 